положения осужденного и его семьи, а также суммы заработной платы или иного дохода осужденного.

Ключевые слова: штраф, уполномоченный орган пробации, совокупность приговоров, совокупность преступлений, судебная практика.

Ostapchuk L. H.

\title{
PROBLEMATIC ASPECTS OF PUNISMENT IN FORM OF PENALTY EXECUTION IN UKRAINE
}

Main problems of Criminal Code of Ukraine (2001) in the aspect of improving practice of punishment in form of penalty application are analyzed. Series of lawsuits, concerning application of punishment in form of penalty towards persons, who are guilty in crimes of minor gravity, are examined. The necessity of award of punishment in form of penalty, according to the severity of commited crime, convict and his family's financial position and the sum of convict's salary or the other income, is grounded.

Thus, the punishment in the form of a fine is a property type of punishment which punitive influence is directed at the financial interests of the convicted person. Fine is a punishment where the usage of remedies is excluded, precisely for this reason the purpose of the fine must be determined, first of all, not by the category of committed crime, but by the degree of the person's who committed it, criminal damage. Accordingly, the amount of punitive effects of punishment in form of fines is directly related to its size.

Key words: penalty, authorized probation body, complex of judgements, complex of crimes, judicial opinion.

УДК 343.8

Дем'яненко Ю. О., кандидат психологічних наук, доцент, доцент кафедри психології, Академія Державної пенітенціарної служби, м. Чернігів;

Олефір Л. І.,

викладач кафедри кримінального,

кримінально-виконавчого права та кримінології,

Академія Державної пенітенціарної служби, м.Чернігів;

Михайлова Т. С.,

курсант 132 навчальної групи,

Академія Державної пенітенціарної служби, м. Чернігів

\section{ПЕРСПЕКТИВИ ВПРОВАДЖЕННЯ ПОСТПЕНІТЕНЦАРНОГО СУПРОВОДУ В СИСТЕМУ ВІТЧИЗНЯНОГО ЗАКОНОДАВСТВА}

У статті викладено результати дослідження зарубіжного досвіду підготовки засуджених до звільнення з місиь позбавлення волі. На основі використаних джерел розкрито поняття «пенітенціарна пробачія», охарактеризовані основні функції $і$ завдання органу пробації, а саме: вирішення питань, які вини- 
кають під час підготовки засуджених до звільнення з місиьь позбавлення волі; надання засудженим психокорекційних програм; допомога засудженим у поновленні зв'язків з родиною. Висвітлено процес підготовки до звільнення з місиь позбавлення волі засуджених у Франиії. Наголошено на необхідності дотримання європейських стандартів для виправлення та ресочіалізації засуджених.

Ключові слова: пробачія, допомога засудженому, виправлення, ресочіалізація, постпенітенціарний супровід.

Постановка проблеми. На шляху інтеграції України до Свропейської спільноти одним 3 пріоритетних завдань держави $є$ забезпечення реалізації прав і свобод людини і громадянина, визначених Конституцією України.

Метою статті $\epsilon$ теоретичний аналіз впровадження постпенітенціарного супроводу засуджених та розгляд можливостей і перспектив впровадження відповідної практики в систему пробації України.

Аналіз основних досліджень і публікацій. Теоритичним підгрунтям статті стали праці відомих як вітчизняних, так і зарубіжних учених, які приділяли багато уваги питанням підготовки засуджених до звільнення 3 місць позбавлення волі: Богатирьов І. Г., Джужа О. М., Зубков А. І., Жук О. М., Філімонов О. В., Яковець І. С., Яровий А. О.

Виклад основного матеріалу. Протягом останніх років Україна діє у напрямі вдосконалення законодавства, зокрема, щодо приведення його у відповідність із законодавством країн континентальної Європи, що передбачає наближення українського суспільства до європейських стандартів життя.

Відповідно до Кримінально-виконавчого кодексу кримінально-виконавче законодавство складається як з національного законодавства, так і з міжнародних документів, які ратифіковані Верховною Радою України. У разі ратифікації міжнародного документа він набуває законодавчої сили. Проте не всі міжнародні документи потребують ратифікації. Деякі міжнародні документи мають рекомендаційний характер та встановлюють мінімальні стандарти стосовно захисту прав людини в певній галузі юриспруденції. Сьогодні основними міжнародними документами в галузі захисту прав ув'язнених є Європейські в'язничні правила, розроблені Радою Свропи, та Мінімальні стандартні правила поводження з ув'язненими, ухвалені Радою Організації Об'єднаних Націй. Слід зазначити, що в цих документах приділяється особ- 
лива увага збереженню, відновленню та встановленню соціальних зв'язків засуджених із зовнішнім світом, які повинні позитивно впливати на формування правослухняної поведінки засуджених та сприяти їх швидшій ресоціалізації.

Поряд 3 цим напрямом велика увага приділяється діяльності установ виконання покарань з виправлення та ресоціалізації засуджених щодо надання допомоги в побутовому та трудовому влаштуванні. Як зазначає в своєму монографічному дослідженні Яковець I. С., саме вищезазначені недоліки є головною причиною вчинення злочинів особами, які відбули покарання. До таких же висновків у своїх працях дійшли Боднар I. В., Іваньков О. І., Кревсун О. М., Царюк С. В.

Актуальність цієї теми зумовлена існуючими недоліками в процесі виправлення та ресоціалізації засуджених, неналежна діяльність у сфері надання допомоги в трудовому та побутовому влаштуванні.

3 метою подолання зазначених причин протиправної поведінки осіб, які відбули покарання, законодавець у 2015 році ухвалює Закон «Про пробацію». Згідно з цим Законом кримінальновиконавча інспекція реорганізується в орган пробації та наділяється додатковими функціями.

Досліджуючи зазначений інститут, вважаємо за необхідне більш детально визначити функції, які законодавець покладає на орган пробації. Згідно із Законом України «Про пробацію» вони поділяються за видами пробації. Відповідно до статті 8 цього закону вказано, що видами пробації є досудова пробація; наглядова пробація; пенітенціарна пробація. Саме на пенітенціарну пробацію покладається функція підготовки до звільнення засуджених з місць позбавлення волі.

Пенітенціарна пробація - це підготовка осіб, які відбувають покарання у виді обмеження волі або позбавлення волі на певний строк, до звільнення з метою трудового і побутового влаштування таких осіб після звільнення за обраним ними місцем проживання [3]. Слід зазначити, що це питання регулюється не тільки Законом України «Про пробацію», а й Кримінально-виконавчим кодексом, у якому в статті 156 зазначено, що уповноважений орган з питань пробації разом з адміністрацією установи виконання покарань не пізніше ніж за три місяці до закінчення строку пока- 
рання у виді обмеження або позбавлення волі на певний строк організовує здійснення заходів щодо сприяння засудженим, які готуються до звільнення, у визначенні місця проживання після звільнення, влаштуванні до спеціалізованих установ для звільнених, госпіталізації до закладів охорони здоров'я (за потреби), працевлаштуванні після звільнення працездатних осіб [1]. Також необхідно наголосити, що цьому питанню приділяється увага i Законом України «Про соціальну адаптацію осіб, які відбувають чи відбули покарання у виді обмеження волі або позбавлення волі на певний строк».

На перший погляд може скластися враження про належне законодавче закріплення цього виду діяльності. Проте, як свідчать статистичні дані повторного вчинення злочинів після відбування покарання, дослідження вітчизняних науковців, а також аналіз проведеного нами опитування практичних працівників органів пробації, на практиці виникає низка проблемних питань, які потребують законодавчого вирішення.

Досліджуючи питання щодо розвитку інституту пробації, слід звернути увагу на точку зору Вовка В. М., який зазначає, що одним 3 актуальних питань у діяльності органу пробації в сучасних умовах $\epsilon$ вирішення питань, пов'язаних із задоволенням першочергових, базових потреб звільнених, а також потреб у безпеці (іжа, одяг, житло, захищеність тощо) для забезпечення основних умов життєдіяльності особистості, які полягають у відновленні документів, що засвідчують особу, а також створюють умови для отримання можливих пільг тощо; визначенні місця проживання; працевлаштування; вирішенні питань, пов'язаних зі здоров'ям [2, с. 13].

Вирішення питання влаштування на роботу як можливості легального отримання коштів для забезпечення первинних потреб, пов'язаних з харчуванням, одягом тощо, є дуже важливим фактором як позитивної соціалізації, так і зниження ймовірності рецидиву злочину.

Законодавством передбачено пільги для влаштування цієї категорії громадян на роботу. Проте на практиці більшість звільнених осіб мають труднощі із влаштуванням на роботу через брак належної освіти, кваліфікації. Крім того, факт перебування в ус- 
тановах виконання покарань є стигматизуючим, таким, що викликає пересторогу у роботодавця.

Інша проблема, на якій необхідно зосередити увагу в діяльності органів та установ виконання покарань, пов'язана 3 потребами у спілкуванні та налагодженні стосунків 3 певними соціальними групами (сім'я, трудовий колектив тощо) та іншими суспільними потребами, що виникають із входженням особи в нове мікросередовище: налагодження взаємин зі своєю сім'єю (3 батьками, дружиною/чоловіком, дітьми); взаємини 3 колишніми друзями та знайомими; взаємодія 3 суспільними інститутами; вироблення навичок поведінки у взаємодії з оточенням [2, с. 14].

Факт налагодження позитивних стосунків звільненої особи 3 сім'єю (батьки, дружина, діти) є необхідною умовою для соціалізації та подолання існуючих у зв'язку з ізоляцією проблем.

Окремою актуальною темою, пов'язаною 3 соціальними зв'язками засуджених та осіб, які звільняються 3 місць позбавлення волі, $€$ налагодження взаємин 3 протилежною статтю, встановлення довготривалих стосунків, створення сім'̈і для тих осіб, які до засудження не перебували в сімейних відносинах або ж розірвали їх у зв’язку з ув'язненням [2, с.15].

Нерідко через відсутність адекватних навичок спілкування, специфічні ціннісні орієнтири контакти 3 протилежною статтю $є$ не тривалими, поверхневими, з частою зміною партнерів. Наслідки таких стосунків можуть мати психотравмуючий характер та призводити до внутрішньоособистісних конфліктів.

Розглядаючи питання виправлення та ресоціалізації засуджених, підготовки їх до звільнення, слід звернутись до досвіду розвинутих країн Європи, які мають тривалий досвід залучення служби пробації у тісній взаємодії з установами виконання покарань до діяльності, пов'язаної з трудовим та побутовим влаштуванням осіб, які відбули покарання, запобігання їх подальшій злочинній діяльності.

Так, у Франції з метою підготовки осіб до звільнення створені центри напіввільного режиму та центри полегшеного покарання, в яких діє більш ліберальний режим утримання [4].

Засудженим, які утримуються у центрах напіввільного режиму, дозволяється залишати установу вдень задля роботи, навчання, лікування, вирішення побутових проблем тощо. Однак вста- 
новлюються чіткі правила повернення до центру у визначений час. Такі центри більше схожі на невеликі готелі чи хостели. У них засуджений самостійно собі готує, прибирає, купує продукти харчування, в нього немає чітко регламентованого режиму відбування покарання.

Засуджений у цих установах має необхідну побутову техніку, доступ до освітніх програм, метою яких є навчитись ними користуватись та адаптуватись у цивільному суспільстві після відбуття покарання. У центрах напіввільного режиму створені робочі місця для осіб, які в них утримуються, надається можливість перепідготовки засуджених до нових професій. Особи, які утримуються в цих установах, можуть відвідувати кафе, кінотеатри, театри, знайомитися з новими людьми і перебувати в них удома [4].

На підставі розгляду питань про порядок підготовки звільнення засуджених $з$ місць позбавлення волі у Франції можемо стверджувати, що зарубіжний досвід яскраво свідчить про те, що якість та ефективність виправлення і реалізація засуджених перебуває на високому рівні. Для української системи виконання покарань, в контексті пенітенціарних реформ, $є$ бажаним здійснення контролю за працевлаштуванням засуджених, звільнених 3 місць позбавлення волі.

Дослідження теоретичних та практичних заходів зарубіжного досвіду діяльності системи виконання покарань та наукових праць сучасних науковців дають можливість стверджувати, що діяльність органів та установ виконання покарань у сфері надання допомоги у побутовому та трудовому влаштуванні засуджених, які звільняються 3 місць позбавлення волі, головним чином повинна бути спрямована на підтримку та відновлення їх соціальних зв'язків та надання допомоги в адаптації у цивільному суспільстві, а для цього необхідно внести зміни в національне законодавство 3 метою закріплення органу пробації в системі органів, які здійснюють діяльність 3 надання допомоги у трудовому та побутовому влаштуванні осіб, які звільненні з установ виконання покарань.

Висновки. Беручи до уваги вищезазначене, на нашу думку, недостатньо визначеною $є$ точка зору законодавця 3 приводу введення обмеження пробації, яка застосовується лише під час підготовки до звільнення засуджених. Цим звужуються функції, 
які покладені на орган пробації в країнах світу, а саме залишаємо поза увагою постпенітенціарний супровід особи після звільнення 3 місць позбавлення волі, що є не тільки не логічним, а й негативно впливає на весь комплекс засобів, які були спрямовані на виправлення та ресоціалізацію засуджених.

Саме тому ми вважаємо за необхідне внесення змін до Закону, тим самим слід закріпити за органом пробації функцію постпенітенціарного супроводу засуджених після звільнення 3 місць позбавлення волі. Це не тільки дозволить контролювати поведінку колишнього засудженого, запобігати його можливій протиправній поведінці, а й надасть йому необхідне підгрунтя для адаптації в соціальному середовищі.

\section{Список використаних джерел}

1. Кримінально-виконавчий кодекс України. URL: http://zakon0.rada.gov.ua/laws/show/1129-15. (дата звернення 17.09.2017).

2. Підготовка до звільнення осіб, які відбувають покарання у виді обмеження або позбавлення волі на певний строк, у тому числі неповнолітніх: методичний посібник / Вовк В. М., Журавель Т. В., Калівошко В. М. та ін.; за заг. ред. Журавель Т. В., Пилипас Ю. В. Київ, 2012. 168 с.

3. Про пробацію: Закон України від 5 лютого 2015 р. № 160-VIII. URL: http://zakon5.rada.gov.ua/laws/show/160-19. (дата звернення 17.09.2017).

4. Code pénale 1810 URL: http://ledroitcriminel.free.fr/ la_legislation_criminelle/anciens_textes/code_penal_1810/code_penal_1810_1. htm. (дата звернення 17.09.2017).

\section{Демьяненко Ю. А., Олефир Л. И., Михайлова Т. С. ПЕРСПЕКТИВЫ ВНЕДРЕНИЯ ПОСТПЕНИТЕНЦИАРНОГО СОПРОВОЖДЕНИЯ В СИСТЕМУ ОТЕЧЕСТВЕННОГО ЗАКОНОДАТЕЛЬСТВА}

В статье изложены результаты исследования зарубежного опыта подготовки осужденных к освобождению из мест лишения свободы. На основе использованной литературы раскрыто понятие «пенитенциирная пробация». Охарактеризовань основные функции и задачи органа пробачии, а именно: решение вопросов, возникающих при подготовке осужденных к освобождению с мест лишения свободы; предоставление осужденным психокоррекционных программ; помощь осужденным в восстановлении связей с семьей.

Освещен прочесс подготовки к освобождению из мест лишения свободы осужденных во Франциии. Сделано акцент на необходимости соблюдения европейских стандартов для исправления и ресоциализации осужденных.

Ключевые слова: пробация, помощь осужденному, исправления, ресоциализация, постпенитенцииарное сопровождение. 


\section{Demyanenko Yu. O., Olefir L. I., Mikhailova T. S. PROSPECTS FOR INTRODUCTION OF POST-PENITENTIARY SUPPORT IN THE SYSTEM OF DOMESTIC LEGISLATION}

In the article the author gives the results of the research of foreign experience in preparing convicts for release from the places of imprisonment. On the basis of the used sources the author exposes concept «Penitentiary probation». The author describes the basic functions and tasks such as: solving the problems which arise up during the preparation of convicts for release from places of imprisonment; granting the convicts with psychological and correctional programmes; helping the convicts to renew the relationships with their families. The author describes the process of the preparation for release of convicts from the places of imprisonment in France. The author marks the observance of European standards for the correction and resocialization of convicts.

Key words: probation, convict's assistance, correction, resocialization, postpenitentiary supervision.

УДК 343.2/.7

Єрмак О. В., кандидат юридичних наук, доцент кафедри кримінального, кримінально-виконавчого права та кримінології, Академія Державної пенітенціарної служби, м. Чернігів

\section{КОНФІСКАЦІЯ МАЙНА В УКРАЇНІ І ДЕЯКИХ ДЕРЖАВАХ-ЧЛЕНАХ ЄВРОПЕЙСЬКОГО СОЮЗУ : КОМПАРАТИВІСТСЬКИЙ АСПЕКТ}

Стаття присвячена огляду кримінального законодавства деяких державчленів Свропейського Союзу та Украӥни в компаративістському аспекті. Здійснено порівняння конфіскації майна в Україні та деяких державах-членах $\epsilon_{8-}$ ропейського Союзу. Зроблено висновок, шуо конфіскачія майна широко представлена в кримінальному праві держав-членів Свропейського Союзу.

Ключові слова: кримінальне право, засоби кримінально-правового характеру, інші засоби кримінально-правового характеру, покарання, конфіскація майна, спеціальна конфіскація.

Постановка проблеми. Згідно з Розділом I Закону України «Про Загальнодержавну адаптацію законодавства України до законодавства Європейського Союзу» від 18 березня 2004 року адаптація законодавства України до законодавства ЄС є пріоритетною складовою процесу інтеграції України до Європейського Союзу, що, в свою чергу, є пріоритетним напрямом української зовнішньої політики. Метою адаптації законодавства України до 